\title{
Summary of Oceanographic and Water-Quality Measurements in Rachel Carson National Wildlife Refuge, Wells, Maine, in 2013
}

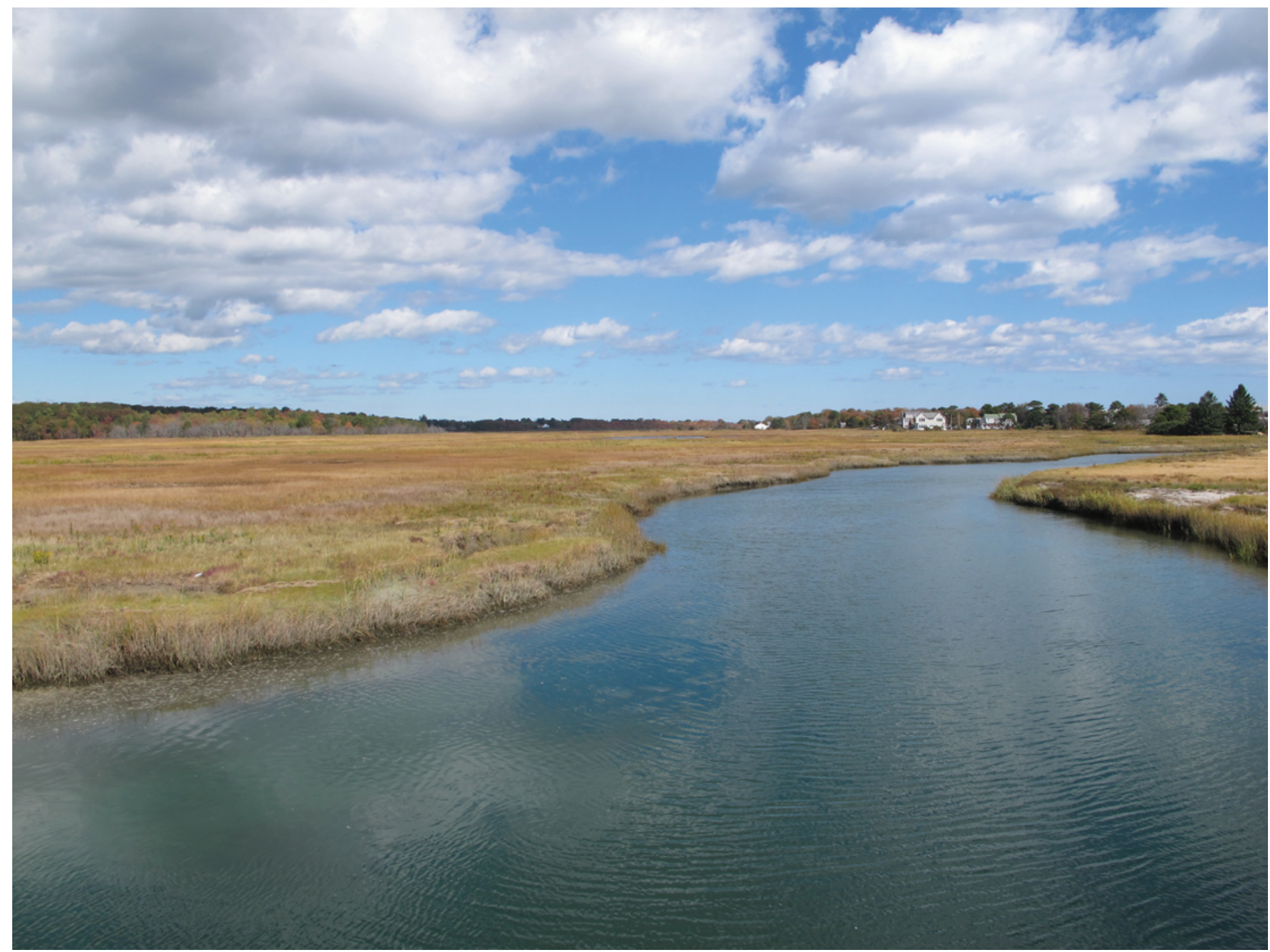

Open-File Report 2015-1072 
Cover. Upstream view from Bourne Avenue site. Photograph by Jonathan Borden. 


\section{Summary of Oceanographic and Water-Quality Measurements in Rachel Carson National Wildlife Refuge, Wells, Maine, in 2013}

By Ellyn T. Montgomery, Neil K. Ganju, Patrick J. Dickhudt, Jonathan Borden, Marinna A. Martini, and Sandra M. Brosnahan

Open-File Report 2015-1072 


\title{
U.S. Department of the Interior SALLY JEWELL, Secretary
}

\section{U.S. Geological Survey \\ Suzette M. Kimball, Acting Director}

\author{
U.S. Geological Survey, Reston, Virginia: 2015
}

For more information on the USGS - the Federal source for science about the Earth, its natural and living resources, natural hazards, and the environment-visit http://www.usgs.gov/ or call 1-888-ASK-USGS.

For an overview of USGS information products, including maps, imagery, and publications, visit http://www.usgs.gov/pubprod/.

Any use of trade, firm, or product names is for descriptive purposes only and does not imply endorsement by the U.S. Government.

Although this information product, for the most part, is in the public domain, it also may contain copyrighted materials as noted in the text. Permission to reproduce copyrighted items must be secured from the copyright owner.

Suggested citation:

Montgomery, E.T., Ganju, N.K., Dickhudt, P.J., Borden, Jonathan, Martini, M.A., and Brosnahan, S.M., 2015, Summary of oceanographic and water-quality measurements in Rachel Carson National Wildlife Refuge, Wells, Maine, in 2013: U.S. Geological Survey Open-File Report 2015-1072, 17 p., http://dx.doi.org/10.3133/ofr20151072.

ISSN 2331-1258 (online) 


\section{Contents}

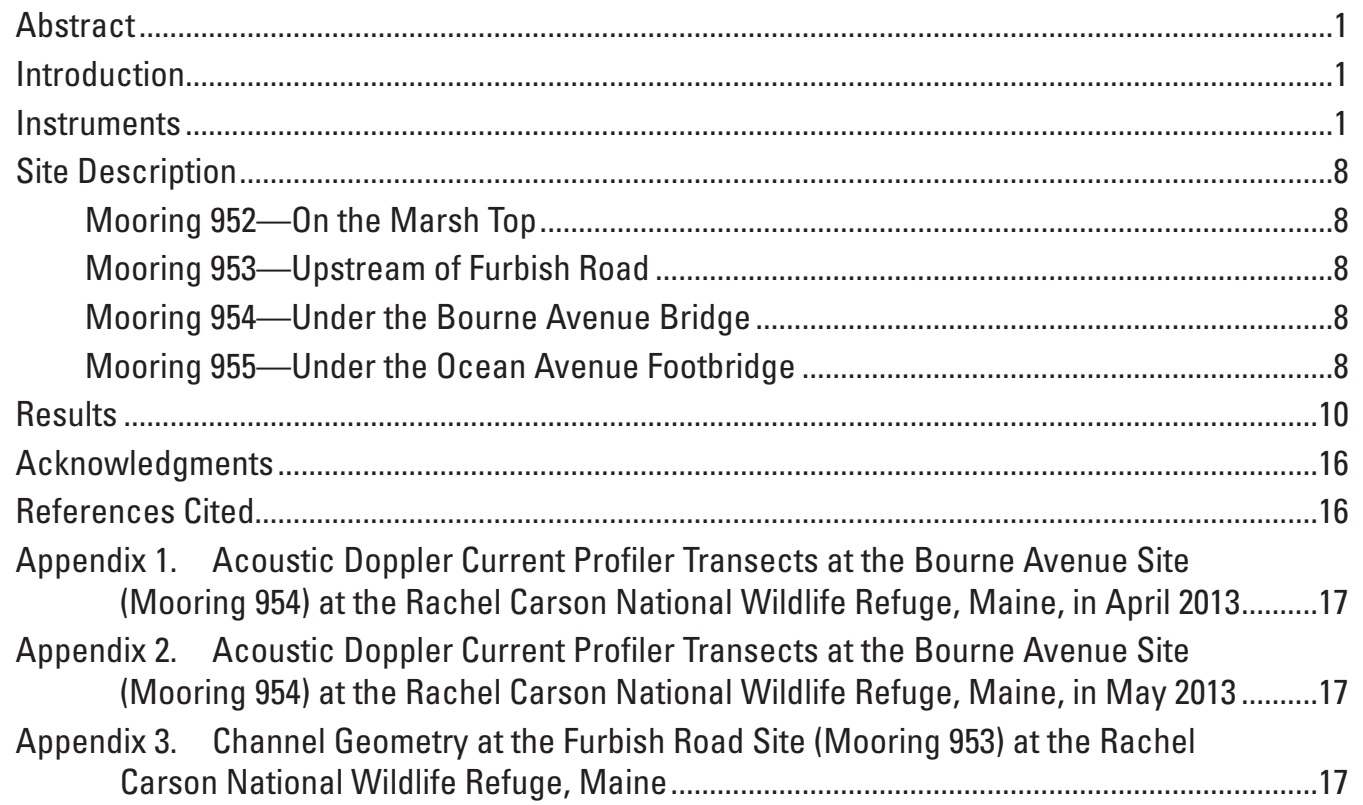

\section{Figures}

1. Maps showing a regional view of the study area in southern Maine

2. Satellite images showing enlarged views of the marsh and study sites showing detail of the channel and surrounding wetlands.......

3. Photograph showing the Onset HOBO weather station mounted on a tower as deployed at site 952 .

4. Photograph showing a WET Labs ECO NTUSB sensor with wiper and a Sea-Bird Electronics model 39 pressure-temperature sensor as deployed at site 952 at the base of the meteorological tower....

5. Photograph showing a SonTek/YSI 6-Series multiparameter sonde with SonTek-IO flow monitor on a grid platform, as deployed at site 953, shown at low tide.

6. Photograph showing a Nortek Aquadopp velocity profiler mounted on a grid platform similar to that used at site 954 .

7. Photograph showing a WET Labs ECO NTUSB sensor with wiper above the Sea-Bird Electronics MicroCAT (model 37) as deployed at site 955, with the ratchet strap used to attach the instruments to the piling .....

8. Photograph showing the SonTek/YSI 6-Series multiparameter sonde and SonTek-IO flow monitor at site 953 prior to reprovisioning

9. Photograph showing typical fouling of the sensors on a SonTek/YSI 6-Series multiparameter sonde....

10. Photograph showing the Nortek Aquadopp velocity profiler recovered at site 954 with barnacle growth accumulated during the entire 9-month deployment.

11. Photograph showing corrosion occurred on the WET Labs ECO NTUSB sensor wipers 
12. Chart presenting the data available for each sensor at each site between

March 27 and December 9, 2013.

13. Graphs showing barometric pressure and wind parameters from the meteorological station at site 952 between March 27 and December 9, 2013.

14. Graphs showing air temperature, relative humidity, short wave radiation and photosynthetically active radiation from the meteorological station at site 952 between March 27 and December 9, 2013.

15. Graphs showing water temperature, pressure, salinity, pH and turbidity at site 953, Furbish Road, between March 27 and December 9, 2013.

16. Graphs showing water temperature, pressure, flow, volume, and stage from the SonTek-I0 flow monitor sensor at site 953, Furbish Road, between March 27 and December 9, 2013.

17. Graphs showing water temperature, pressure, salinity and turbidity from the SonTek/YSI 6-Series sonde at site 954, Bourne Avenue, between March 27 and December 9, 2013

18. Graphs showing the east and north components of velocity and pressure from the Nortek Aquadopp velocity profiler at site 954, Bourne Avenue, between March 27 and December 9, 2013

19. Graphs showing water temperature, pressure, salinity, and turbidity from the Sea-Bird Electronics MicroCAT and Eco NTUSB sensors at site 955, the 0cean Avenue Footbridge, between March 27 and December 9, 2013

\section{Table}

1. Mooring log. .9

\section{Conversion Factors}

International System of Units to Inch/Pound

\begin{tabular}{lll}
\hline \multicolumn{1}{c}{ Multiply } & By & \multicolumn{1}{c}{ To obtain } \\
\hline & Length & \\
\hline meter $(\mathrm{m})$ & 3.281 & foot $(\mathrm{ft})$ \\
kilometer $(\mathrm{km})$ & 0.6214 & mile $(\mathrm{mi})$ \\
kilometer $(\mathrm{km})$ & 0.5400 & mile, nautical $(\mathrm{nmi})$ \\
meter $(\mathrm{m})$ & 1.094 & yard $(\mathrm{yd})$ \\
\hline & Volume & \\
\hline cubic meter $\left(\mathrm{m}^{3}\right)$ & 35.31 & cubic foot $\left(\mathrm{ft}^{3}\right)$ \\
\hline & Flow rate & \\
\hline meter per second $(\mathrm{m} / \mathrm{s})$ & 3.281 & foot per second $(\mathrm{ft} / \mathrm{s})$ \\
\hline
\end{tabular}

Temperature in degrees Celsius $\left({ }^{\circ} \mathrm{C}\right)$ may be converted to degrees Fahrenheit $\left({ }^{\circ} \mathrm{F}\right)$ as ${ }^{\circ} \mathrm{F}=\left(1.8 \times{ }^{\circ} \mathrm{C}\right)+32$. 


\section{Datum}

Vertical coordinate information is referenced to the North American Vertical Datum of 1988

(NAVD 88).

Horizontal coordinate information is referenced to the North American Datum of 1983 (NAD 83).

\section{Supplemental Information}

Pressure measured underwater is given in decibars (dbar).

Air pressure is given in millibars (mbar).

Conductivity is given in siemens per meter $(\mathrm{S} / \mathrm{m})$.

Salinity is given as practical salinity units (PSU).

Turbidity is given as nephelometric turbidity units (NTU).

Short wave radiation is given in watts per square meter $\left(\mathrm{w} / \mathrm{m}^{2}\right)$.

Photosynthetically active radiation is given in microeinsteins $(\mu \mathrm{E})$.

Water flow is given as cubic meters per second $\left(\mathrm{m}^{3} / \mathrm{s}\right)$.

Current direction is the direction the current is flowing to in degrees clockwise from true north.

Wind direction is the direction the wind is coming from in degrees clockwise from true north.

Wave direction is the direction from which waves are propagating, measured clockwise from true north. Flow is positive upstream because of the orientation of the sensor.

\section{Abbreviations}

$\begin{array}{ll}\text { ADCP } & \text { acoustic Doppler current profiler } \\ \text { dbar } & \text { decibars } \\ \text { EPIC } & \text { Equatorial Pacific Information Collection } \\ \text { mab } & \text { meters above bottom } \\ \text { mbar } & \text { millibars } \\ \text { NetCDF } & \text { Network Common Data Form } \\ \text { NTU } & \text { nephelometric turbidity units } \\ \text { PAR } & \text { photosynthetically active radiation } \\ \text { PSU } & \text { practical salinity units } \\ \text { RCNWR } & \text { Rachel Carson National Wildlife Refuge } \\ \text { SBE } & \text { Sea-Bird Electronics } \\ \text { USGS } & \text { U.S. Geological Survey }\end{array}$





\title{
Summary of Oceanographic and Water-Quality Measurements in Rachel Carson National Wildlife Refuge, Wells, Maine, in 2013
}

\author{
By Ellyn T. Montgomery, Neil K. Ganju, Patrick J. Dickhudt, Jonathan Borden, Marinna A. Martini, and \\ Sandra M. Brosnahan
}

\begin{abstract}
Suspended-sediment transport is a critical element controlling the geomorphology of tidal wetland complexes. Wetlands rely on organic material and inorganic sediment deposition to maintain their elevation relative to sea level. The U.S. Geological Survey performed observational deployments to measure suspended-sediment concentration and water flow rates in the tidal channels of the wetlands in the Rachel Carson National Wildlife Refuge in Wells, Maine. The objective was to characterize the sediment-transport mechanisms that contribute to the net sediment budget of the wetland complex. We deployed a meteorological tower, optical turbidity sensors, and acoustic velocity meters at sites on Stephens Brook and the Ogunquit River between March 27 and December 9, 2013. This report presents the time-series oceanographic and atmospheric data collected during those field studies. The oceanographic parameters include water velocity, depth, turbidity, salinity, temperature, and $\mathrm{pH}$. The atmospheric parameters include wind direction, speed, and gust; air temperature; air pressure; relative humidity; short wave radiation; and photosynthetically active radiation.
\end{abstract}

\section{Introduction}

This report presents oceanographic and water-quality observations measured by the U.S. Geological Survey (USGS) in the Rachel Carson National Wildlife Refuge (RCNWR) in Wells, Maine, between March 27 and December 9, 2013 (fig. 1). Measurements were made at two locations on Stevens Brook, upstream of where it merges with the Ogunquit River, and at two locations downstream, nearer the ocean. The study area within RCNWR is a marsh and wetland complex. Wetlands are inherently unstable features that evolve because of multiple factors, including sea-level rise, atmospheric forcing, and invasive species (Ganju and others, 2013). The suspended-sediment concentrations and net fluxes to and from wetlands can provide insight into the relative stability of the marsh plain.

Between March and December 2013, near-continuous measurements were collected at four sites along the marsh (moorings 952, 953, 954, 955; fig. 2). Twice during the eight-month deployment, the equipment at each site was recovered, data were downloaded, and batteries were changed. During the time when the instruments were out of the water, no data were collected. The sampling scheme was planned to resolve short duration events as well as longer term trends. Measurements from a suite of sensors were made in the water and in the atmosphere to calculate the parameters relevant to sediment fluxes and their forcing.

\section{Instruments}

In this experiment, autonomous instruments, with self-contained power and onboard data storage, were deployed at multiple sites at the RCNWR to quantify sediment flux. Measurements made in the water included temperature, salinity, velocity, pressure (depth), $\mathrm{pH}$, and turbidity. Complimentary atmospheric measurements were made to help determine forcing mechanisms. These atmospheric measurements included wind speed, direction, and gusts; air temperature; air pressure; relative humidity; short wave radiation; and photosynthetically active radiation.

An Onset HOBO weather station (fig. 3) measured wind direction, speed, and gust; air temperature; pressure; relative humidity; short wave radiation; and photosynthetically active radiation. WET Labs ECO NTUSB turbidity sensors (fig. 4) with wipers intended to prevent fouling of the optical sensor were deployed to provide turbidity measurements. Sea-Bird Electronics model 39 (SBE39; fig. 4) and model 37 (MicroCAT) sensors were used to measure water temperature, pressure, and conductivity. SonTek/YSI 6-Series multiparameter sondes (fig. 5), which can measure a variety of parameters by using 


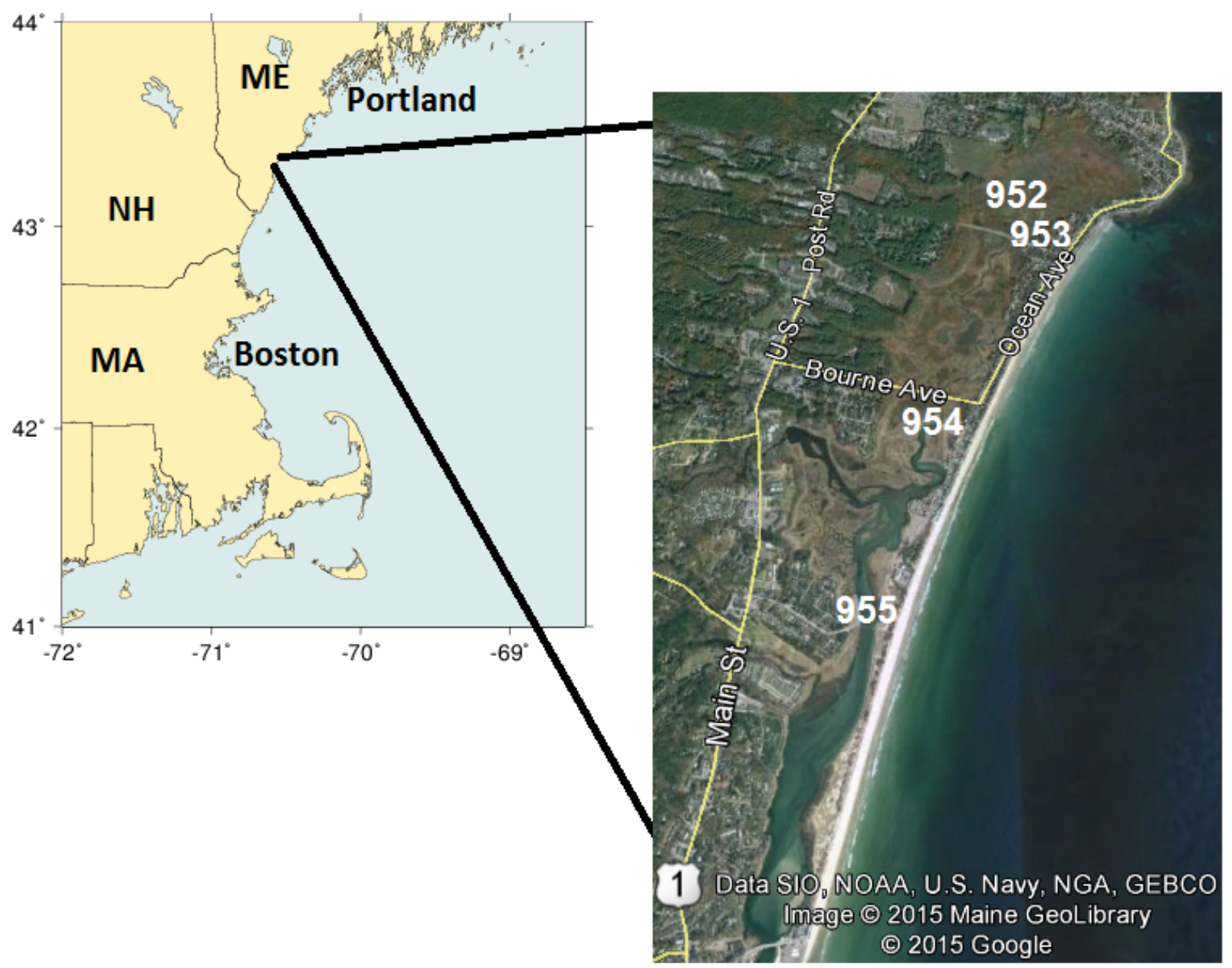

Figure 1. A regional view of the study area in southern Maine. The inset shows locations of the measurement sites. Rd, Road; Ave, Avenue; St, Street; SIO, Scripps Institution of Oceanography; NOAA, National Oceanic and Atmospheric Administration; NGA, National Geospatial-Intelligence Agency; GEBCO, General Bathymetric Chart of the Oceans. Map data (c) 2015 Google, Maine GeoLibrary. 

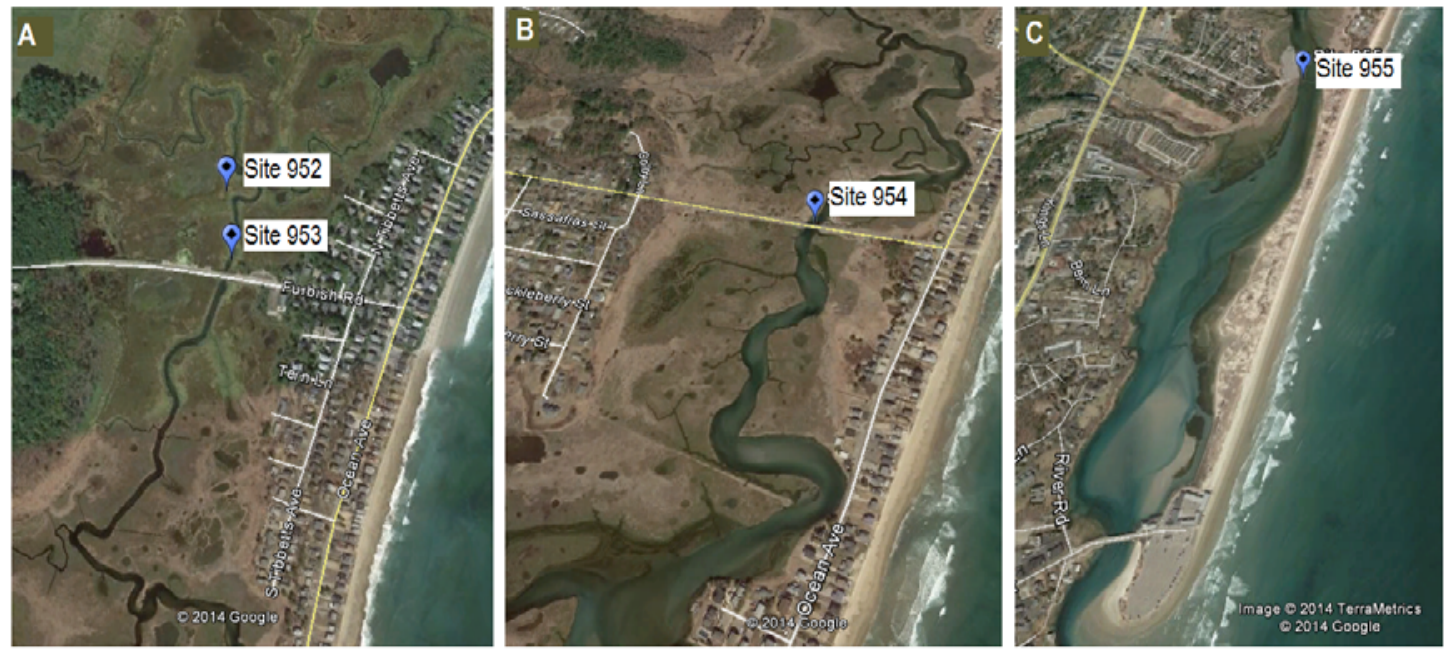

Figure 2. Enlarged views of the marsh and study sites showing detail of the channel and surrounding wetlands. $A$, the upstream sites 952 and 953 on Stephens Brook. B, Bourne Avenue site 954 on the Ogunquit River. C, Ocean Avenue site 955 on the Ogunquit River. Ave, Avenue; Rd, Road; Ln, Lane; St, Street. Map data (C) 2014 Google, TerraMetrics.

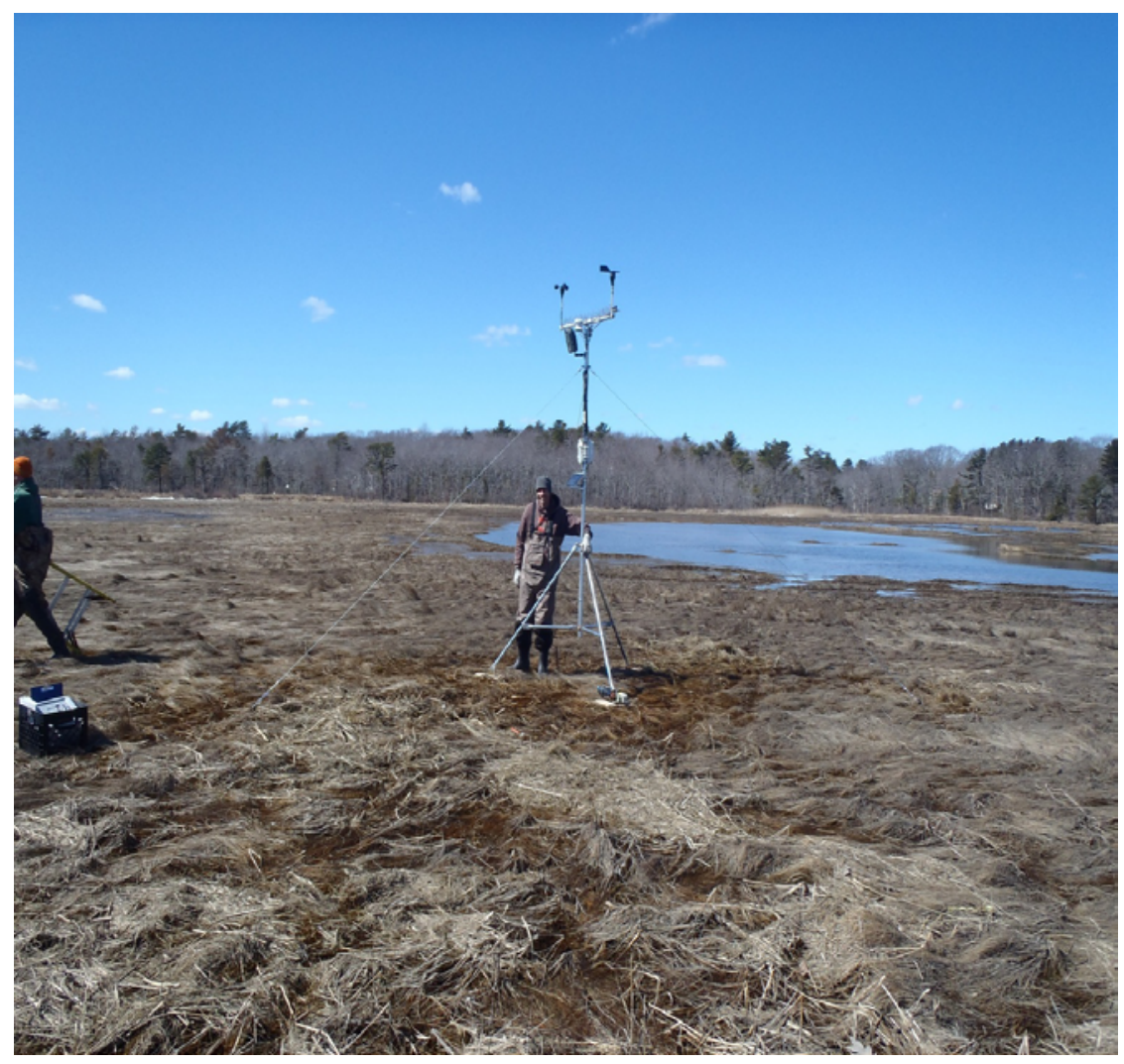

Figure 3. The Onset HOBO weather station mounted on a tower as deployed at site 952. 


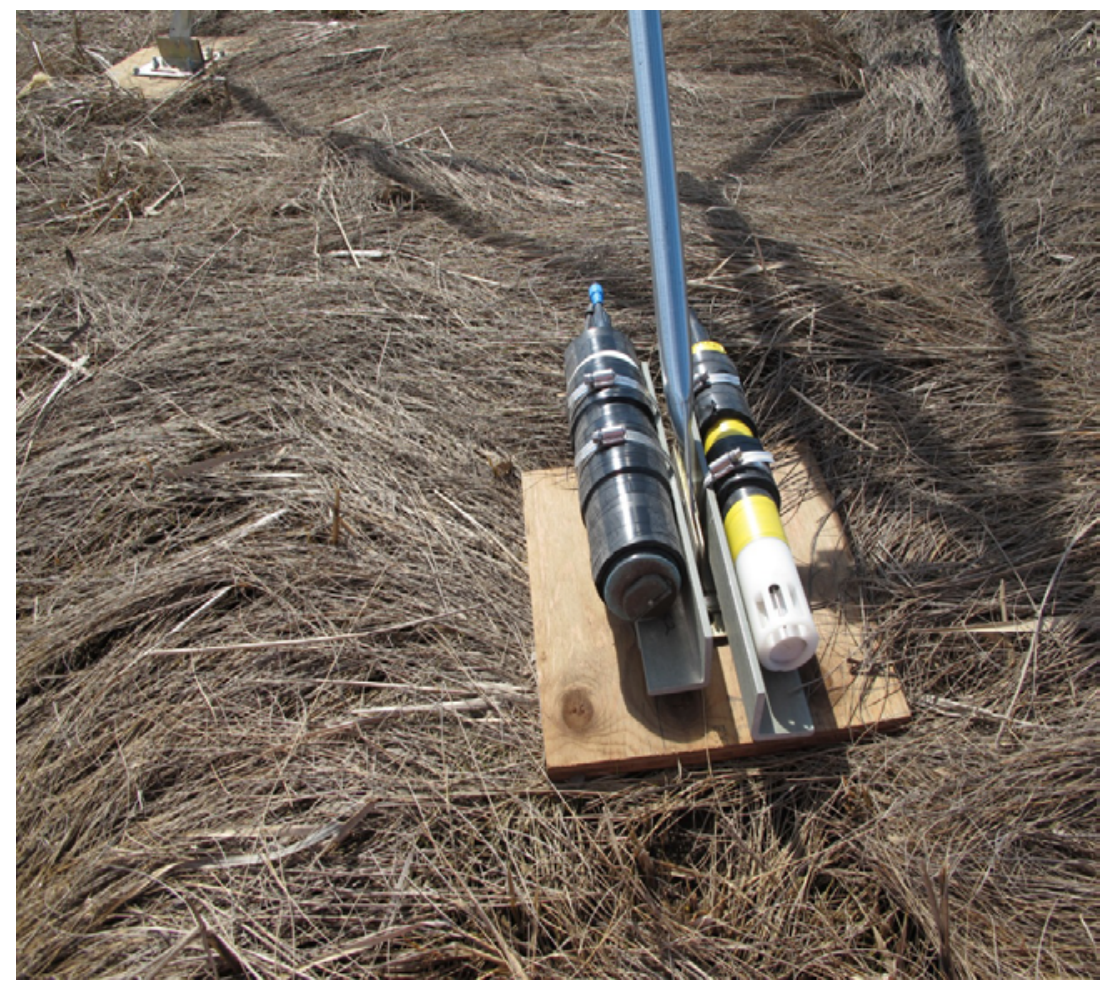

Figure 4. A WET Labs ECO NTUSB sensor with wiper (left) and a Sea-Bird Electronics model 39 pressure-temperature sensor (right) as deployed at site 952 at the base of the meteorological tower.

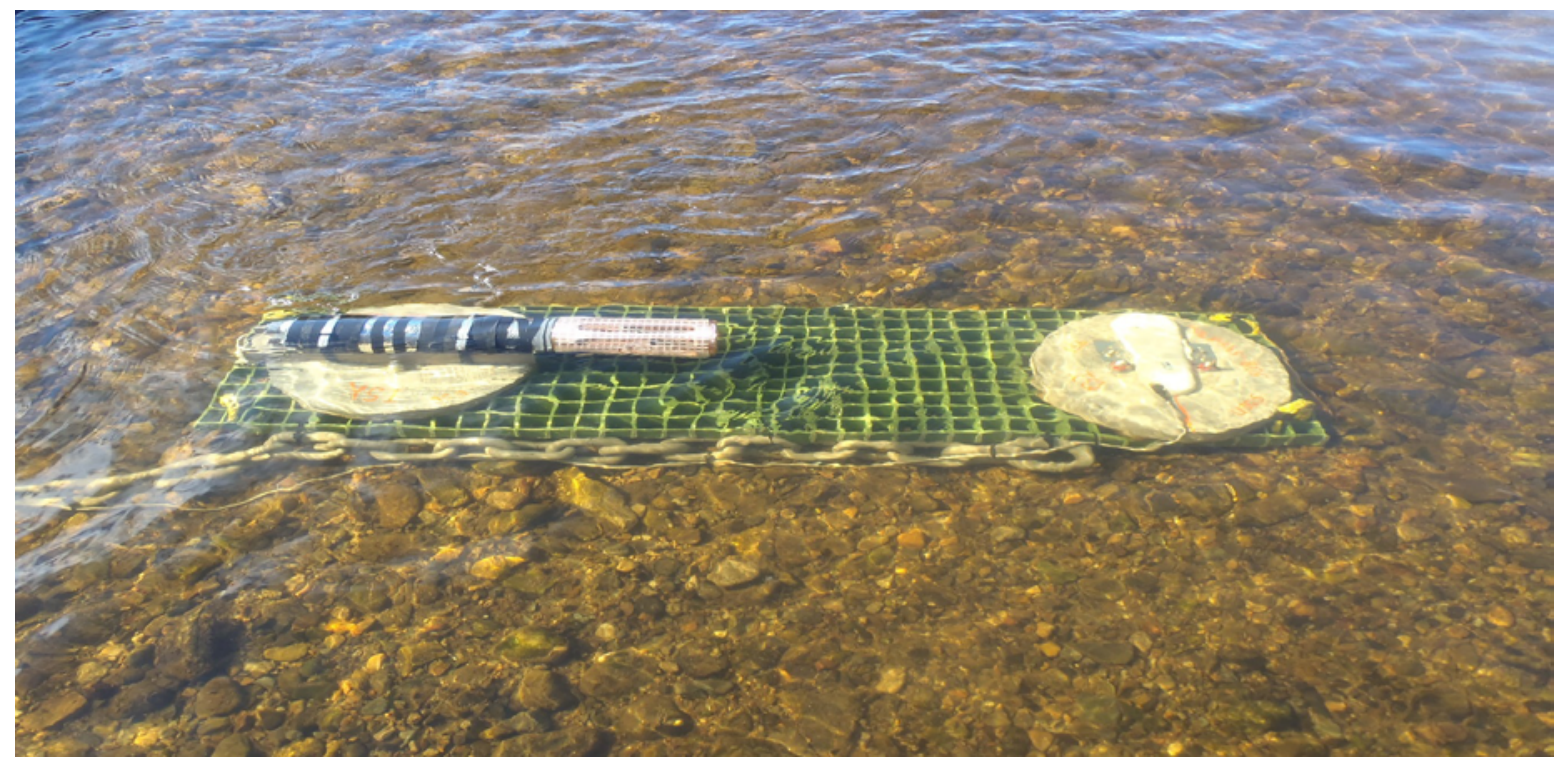

Figure 5. A SonTek/YSI 6-Series multiparameter sonde (left) with SonTek-I0 flow monitor (right) on a grid platform, as deployed at site 953 , shown at low tide. The top of this image points downstream. 
interchangeable probes, were used for the hydrographic measurements. These sondes were mounted on grid platforms that allowed for deployment near the channel bottom, so they would remain submerged at low tide. A Nortek Aquadopp velocity profiler (fig. 6) was deployed at mooring 954, and a SonTek-IQ channel flow monitor (fig. 5) was deployed at mooring 953; both instruments were near the channel bottom to measure vertical profiles of streamflow and bottom pressure. During the experiment, algae and barnacles grew on the sensors (figs. 8-10), and some corrosion was observed (fig. 11). The biological fouling was removed from all the sensors during periodic reprovisionings.

More information about the Nortek Aquadopp velocity profiler, SBE39, MicroCAT sensors, and SonTek/YSI 6-Series sondes is available in the "Instruments" section of Ganju and others (2011). More information about the WET Labs ECO NTUSB turbidity sensors is available in the "Instruments" section of Ganju and others (2012). Links to the at the manufacturer's Web sites are provided as part of the instrument descriptions in the reports referenced.

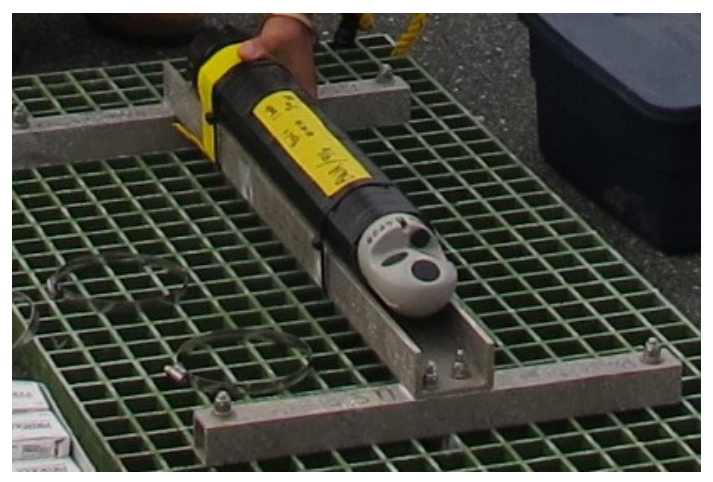

Figure 6. A Nortek Aquadopp velocity profiler mounted on a grid platform similar to that used at site 954 .

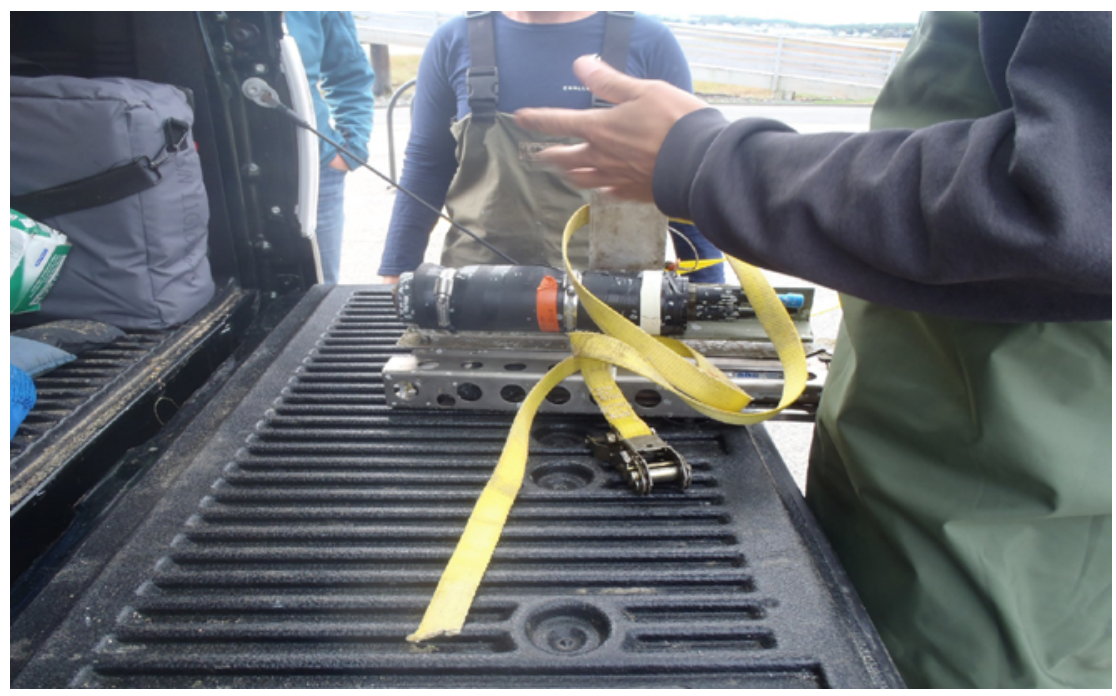

Figure 7. A WET Labs ECO NTUSB sensor with wiper above the Sea-Bird Electronics MicroCAT (model 37) as deployed at site 955, with the ratchet strap used to attach the instruments to the piling. The sensors are to the left of the photograph. 


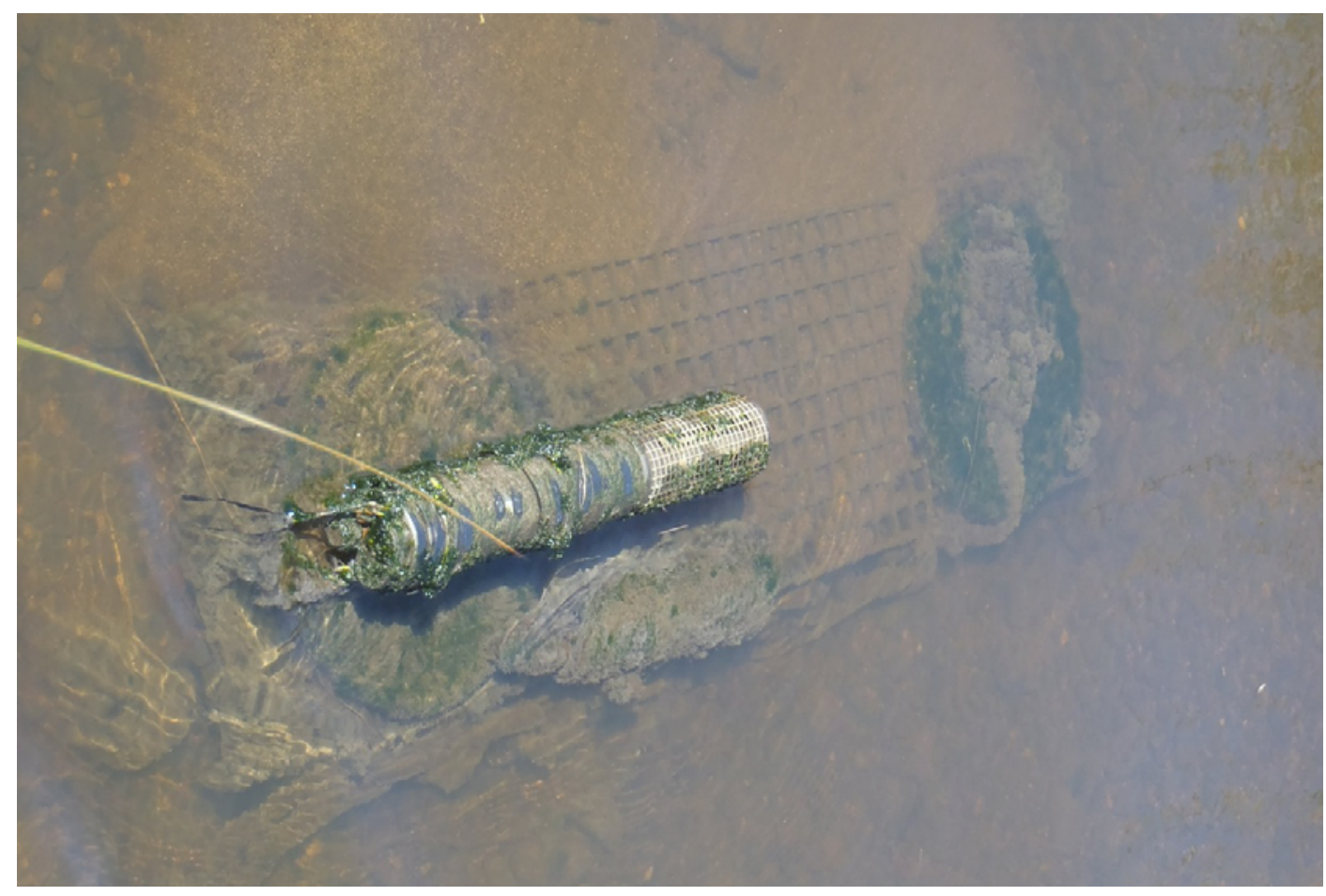

Figure 8. The SonTek/YSI 6-Series multiparameter sonde (left) and SonTek-IQ flow monitor (right) at site 953 prior to reprovisioning. Significant algal growth occurred on both sensors during the deployment.

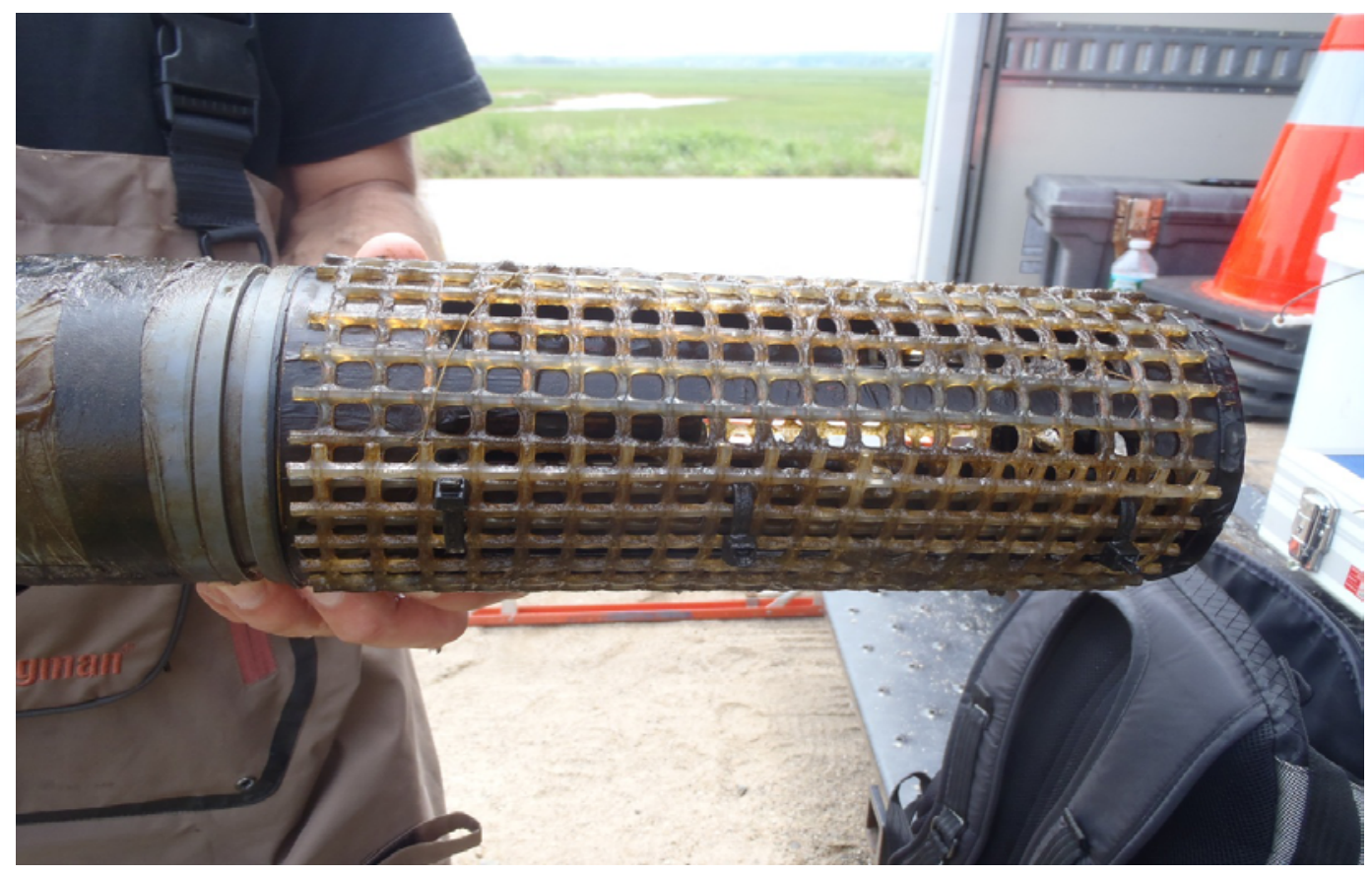

Figure 9. Typical fouling of the sensors on a SonTek/YSI 6-Series multiparameter sonde. The plastic grid is intended to keep large particles and animals away from the sensors. 


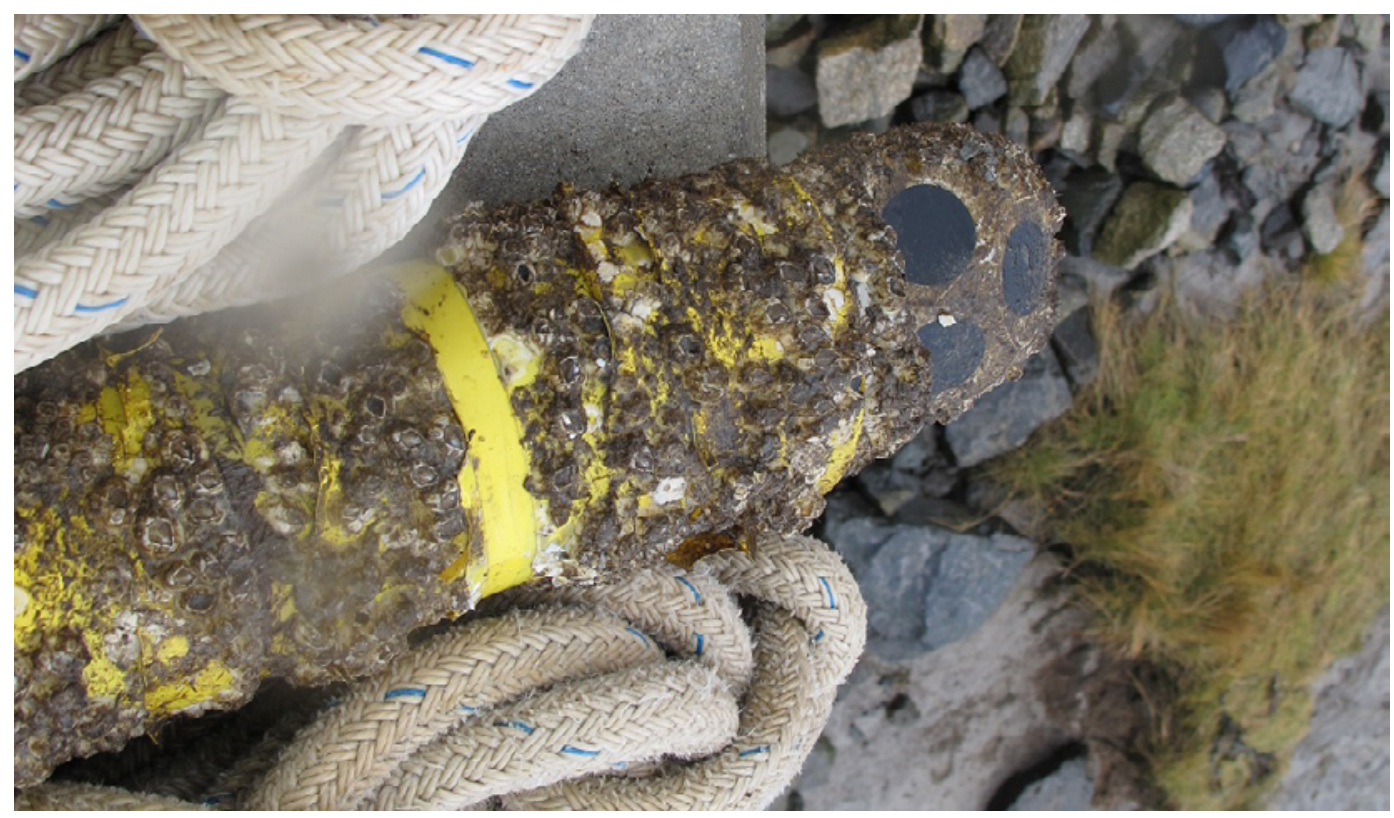

Figure 10. The Nortek Aquadopp velocity profiler recovered at site 954 with barnacle growth accumulated during the entire 9-month deployment. The black transducers at the right were unfouled at recovery.

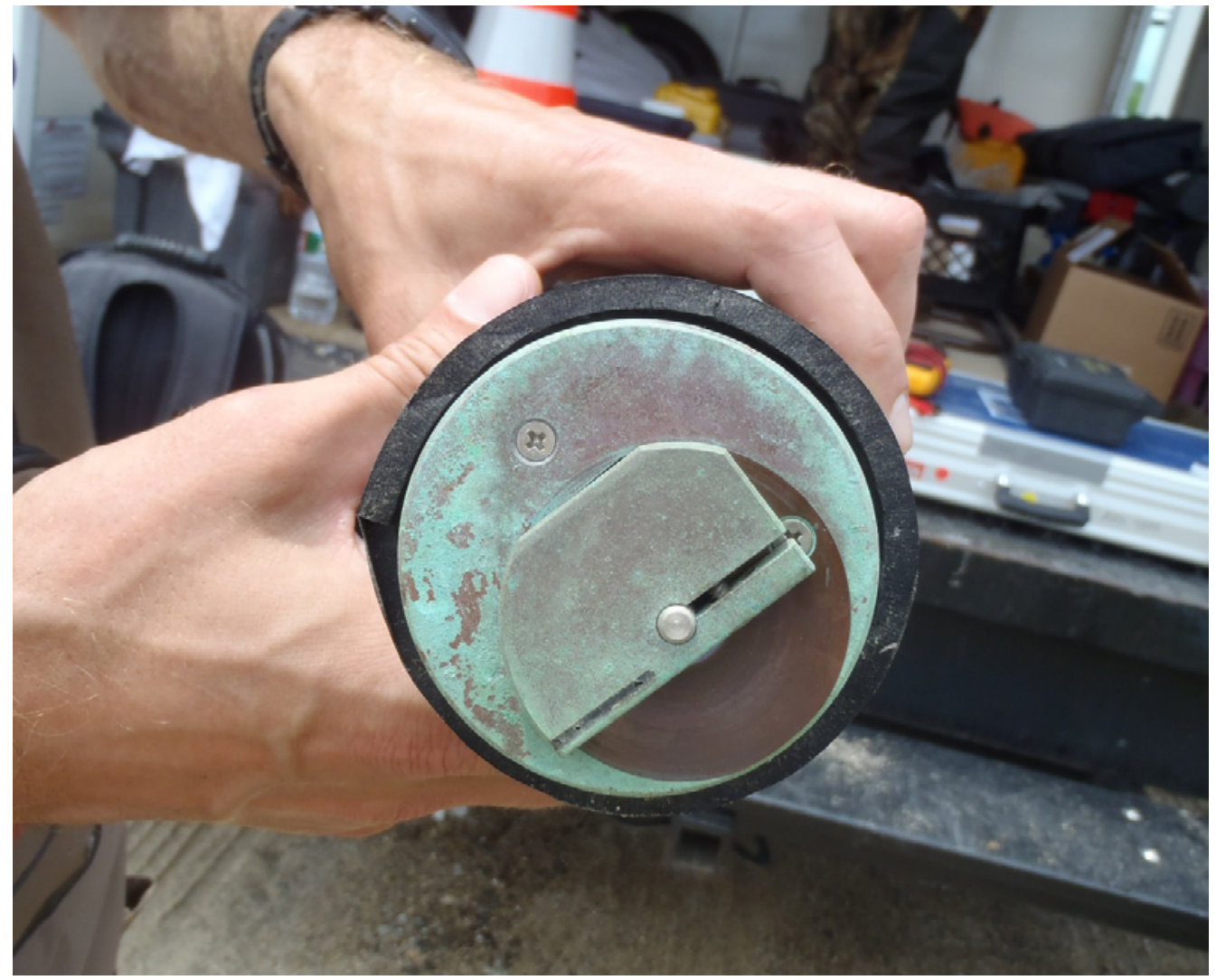

Figure 11. Corrosion occurred on the WET Labs ECO NTUSB sensor wipers. The brown, uncorroded region indicates the wiper was rotating correctly throughout the deployment. 
Deployment-specific details are provided in subsequent sections. The mooring log (table 1) details which instruments were deployed at each site, the serial numbers for each instrument, and the names of data files for each site.

Because of limitations in the instruments' battery and memory capacities, the experiment was broken into three sequential segments. Recovery dates were June 3-4 and September 23-24; therefore in the data there are short gaps corresponding to the periods when the instruments were out of the water. One data file is provided for each temporal segment, along with an aggregated file with all the sensor data for the eight-month period.

The data from all the instruments were stored internally. After each recovery, the manufacturers' software was employed to download the data, apply calibration coefficients, and convert the data to scientific units. These output files were then converted by custom, instrument-specific Matlab programs to Equatorial Pacific Information Collection (EPIC) convention-compliant Network Common Data Form (NetCDF) files for distribution on the USGS Sediment Transport Group's data distribution Web site. Files listed in this report are linked to their locations on the distribution site.

Additional information on data processing, quality assurance and control protocols, file formats, nomenclature, and access methods used by the USGS Woods Hole Coastal and Marine Science Center Sediment Transport Group is provided in Montgomery and others (2008).

\section{Site Description}

During this experiment, four sites along Stephens Brook and the Ogunquit River were occupied along a longitudinal gradient. Each site was assigned a mooring number in our system for managing the details of the deployment. All the sites (fig. 2) can be viewed by opening RCNWR.kml (available on the RCNWR experiment page) in Google Earth and zooming to explore the site locations. Descriptions of the sites and instruments deployed at each site follow. Additional details and links to the data files collected are provided in table 1, the mooring log.

\section{Mooring 952 - On the Marsh Top}

This site was located on the marsh plain north of the bridge at Furbish Road. An Onset HOBO weather station (fig. 3) was mounted on a tower 2 meters (m) above the marsh, with SBE39 and WET Labs ECO NTUSB turbidity sensors mounted at the base of the tower (0.14 $\mathrm{m}$ above the marsh; fig. 4).

\section{Mooring 953-Upstream of Furbish Road}

This was the furthest landward subaqueous site, about 4 kilometers $(\mathrm{km})$ from the mouth of the Ogunquit River. A SonTekIQ flow monitor was deployed on a grate 0.105 meters above bottom (mab), looking upwards to measure water flow. Adjacent to it on the grate, a SonTek/YSI 6-series multiparameter sonde was used to measure water quality at $0.165 \mathrm{mab}$ (fig. 5). In order to retain the spatial reference of the transducers, the SonTek-IQ flow monitor was not removed for cleaning. It was cleaned in place, and data were downloaded through a cabled connection to a computer on the shore.

\section{Mooring 954—Under the Bourne Avenue Bridge}

The next site in the seaward direction was situated under the Bourne Avenue bridge, in an area deeper than mooring 953. The same suite of measurements as those made at Furbish Road were collected at this site by measuring the currents with a Nortek Aquadopp velocity profiler mounted at 0.25 mab, looking upwards, and by measuring water quality with an SonTek/YSI 6-series multiparameter sonde at $0.30 \mathrm{mab}$. In order to retain the spatial reference of the transducers, the Nortek Aquadopp was not removed and reprovisioned with the other instruments. The battery and memory capacity were sufficient to last the entire deployment, but the instrument failed early.

\section{Mooring 955-Under the Ocean Avenue Footbridge}

This furthest seaward site was located $1.6 \mathrm{~km}$ from the river mouth. Sea-Bird Electronics model 37 (MicroCAT) and WET Labs ECO NTUSB sensors were attached to a piling under the Ocean Avenue footbridge. The MicroCAT sensor was mounted at $0.5 \mathrm{mab}$ and the ECO NTUSB sensor was mounted at $0.55 \mathrm{mab}$; both instruments were submerged, even at the lowest low tide. 
Table 1. Mooring log.

\begin{tabular}{|c|c|c|c|c|}
\hline $\begin{array}{l}\text { Mooring identification } \\
\text { number }\end{array}$ & $\begin{array}{c}\text { Site identification } \\
\text { number }\end{array}$ & Instrument & Serial number & Data file(s) \\
\hline \multicolumn{5}{|c|}{ 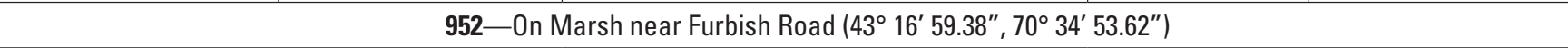 } \\
\hline 9521 & Marsh & $\begin{array}{l}\text { Onset HOBO } \\
\text { U30 Weather Station }\end{array}$ & 10119528 & $\begin{array}{l}\text { 9521Ahlmm-a.nc, } \\
\text { 9521Bhlm-a.nc, } \\
\text { 9521hlm_all-a.nc }\end{array}$ \\
\hline 9522 & Marsh & WET Labs ECO NTUSB sensor & 507 & $\begin{array}{l}\text { 9522Aecn-a.nc, } \\
\text { 9522Becn-a.nc, } \\
\text { 9522Cecn-a.nc, } \\
\text { 9522ecn_all-a.nc }\end{array}$ \\
\hline 9523 & Marsh & Sea-Bird Electronics model 39 sensor & 142 & Available by request \\
\hline \multicolumn{5}{|c|}{ 953-Center of tidal creek upstream of Furbish Road $\left(43^{\circ} 16^{\prime} 55.56^{\prime \prime}, 70^{\circ} 34^{\prime} 54.44^{\prime \prime}\right)$} \\
\hline 9531 & Furbish & SonTek/YSI 6600 multiparameter sonde & 625 & $\begin{array}{l}\text { 9531Aysi-a.nc, } \\
\text { 9531Bysi-a.nc, } \\
\text { 9531Cysi-a.nc, } \\
\text { 9531ysi_all-a.nc }\end{array}$ \\
\hline 9532 & Furbish & SonTek-IQ flow monitor & 1247014 & $\begin{array}{l}\text { 9532Aiqflow-cal.cdf, } \\
\text { 9532Biqflow-cal.cdf, } \\
\text { 9532Ciqflow-cal.cdf, } \\
\text { 9532Aiqprof-cal.cdf, } \\
\text { 9532Biqprof-cal.cdf, } \\
\text { 9532Ciqprof-cal.cdf }\end{array}$ \\
\hline \multicolumn{5}{|c|}{ 954-In channel under bridge at Bourne Avenue $\left(43^{\circ} 16^{\prime} 25.46^{\prime \prime}, 70^{\circ} 35^{\prime} 12.30^{\prime \prime}\right)$} \\
\hline 9541 & Bourne & Nortek Aquadopp velocity profiler & 5379 & 9541aqd-cal.nc \\
\hline 9542 & Bourne & SonTek/YSI 6600 multiparameter sonde & 627,626 & $\begin{array}{l}\text { 9542Aysi-a.nc, } \\
\text { 9542Bysi-q.nc, } \\
\text { 9542Cysi-a.nc, } \\
\text { 9542ysi_all-a.nc }\end{array}$ \\
\hline \multicolumn{5}{|c|}{ 955-In channel on piling under pedestrian bridge at Ocean Avenue $\left(43^{\circ} 15^{\prime} 46.69^{\prime \prime}, 70^{\circ} 35^{\prime} 26.736^{\prime \prime}\right)$} \\
\hline 9551 & Footbridge & Sea-Bird Electronics MicroCAT sensor & 283 & $\begin{array}{l}\text { 9521Amc-a.nc, } \\
\text { 9521Bmc-a.nc, } \\
\text { 9521Cmc-q.nc, } \\
\text { 9521mc_all-a.nc }\end{array}$ \\
\hline 9552 & Footbridge & WET Labs ECO NTUSB sensor & 434 & $\begin{array}{l}\text { 9522Aecn-a.nc, } \\
\text { 9522Becn-a.nc, } \\
\text { 9522Cecn-a.nc, } \\
\text { 9552ecn_all-a.nc }\end{array}$ \\
\hline
\end{tabular}




\section{Results}

Overall, the data-collection effort was successful, and enough data were obtained to support the analysis objectives. Unfortunately, several instruments failed during different periods of the deployment; the causes of failures were determined after recovery and rectified prior to redeployment when possible. A graphical representation of the data availability during this experiment (fig. 12) shows the temporal gaps for each kind of data at each site.

After each recovery, data were retrieved and processed by using proprietary software from the instrument manufacturers and Matlab data-analysis software. Data were edited to remove spurious spikes, times when ice interfered with measurement, and other forms of bad data. Data were then converted to EPIC-compliant variables and placed into NetCDF format. NetCDF files allow for sharing of data in a common format that is machine independent and contains appropriate metadata. Documentation of the USGS oceanographic time-series measurement database can be found in Montgomery and others (2008).

Meteorological data from the marsh site (952) is presented in two parts: (1) the wind speed, direction, gust and pressure variables (fig. 13), and (2) the temperature, relative humidity, and solar radiation and photosynthetically active radiation (PAR) variables (fig. 14). This time series terminated in October because of premature battery failure. The marsh surface temperature and pressure show very high variability because of the sensor's response to being subaerially exposed most of the time. There were only short durations of data when the sensors were wet at the highest high tides, so the SBE39 data is only available on request.

The water-quality parameters collected by the YSI 6-Series sonde at Furbish Road (953) show typical diurnal and seasonal changes (fig. 15). The tidal fluctuations caused the sensor to be dry during some low tides. The pressure record was subtracted from the barometric pressure to determine which records were taken when the sensor was dry. Data at these points were replaced by the fill value. Cold weather at the end of November caused ice formation in the sensors; the data from this period were also removed. The accompanying water flow data from the SonTek-IQ flow monitor (fig. 16) show the tidal dominance in the flow.

The water-quality parameters collected by the YSI 6-Series sonde at Bourne Avenue (954) show tidal influence (fig. 17). The YSI sonde failed to start in the second (summer) deployment, and although the temperature and pressure data are valid, the turbidity, conductivity, and salinity data are not, and they have been removed. The velocity data from the Nortek Aquadopp velocity profiler at this site also ended early because of instrument malfunction. The Aquadopp was not recovered and redeployed when the other instruments were reprovisioned, so its failure was not recognized until December. The recovered data show details of flow throughout the water column. The time series of the east and north velocities from the deepest and a nearsurface bin show a strong tidal signal and increased speeds near the surface (fig. 18).

In addition to the time-series data collected at Bourne Avenue, two 24-hour transects of towed downward-looking acoustic Doppler current profiler (ADCP) measurements were collected at Bourne Avenue to characterize discharge at the site (appendixes 1 and 2).

The water-quality data from the Ocean Avenue footbridge (955) provide a full record of temperature, salinity, pressure and turbidity (fig. 19). The conductivity and salinity of the third (autumn) section of the data record were higher than those recorded in the second (summer) section. For this third section, the Ocean Avenue salinity was also higher than the salinity at the Gulf of Maine mooring B01 (slightly offshore, at 1-m depth); our site has freshwater input, so the salinity should be lower. Consequently, the Ocean Avenue data were adjusted to fit the rest of the time-series by decreasing the conductivity data by $0.4 \mathrm{~S} / \mathrm{m}$ to match the end of the second section, then the salinity data were recomputed, allowing the third section of the data record to conform to the rest of the salinity data for this station.

The data (Montgomery and others, 2015) are publicly served at http://dx.doi.org/10.5066/F7ST7MWS, which contains details of all field activities associated with this project, Google Earth visualizations of deployment locations, and sampling interval information. The edited, final data files can be downloaded from the distribution site or accessed directly by using OPeNDAP via the "Data access via THREDDS" link. File naming conventions for time-series observations are described in the "File Naming Conventions" section of Montgomery and others (2008). Data in formats that do not conform to the structure of the Time-Series Measurement Database (ADCP transects and channel measurements) can be found in the appendixes. 


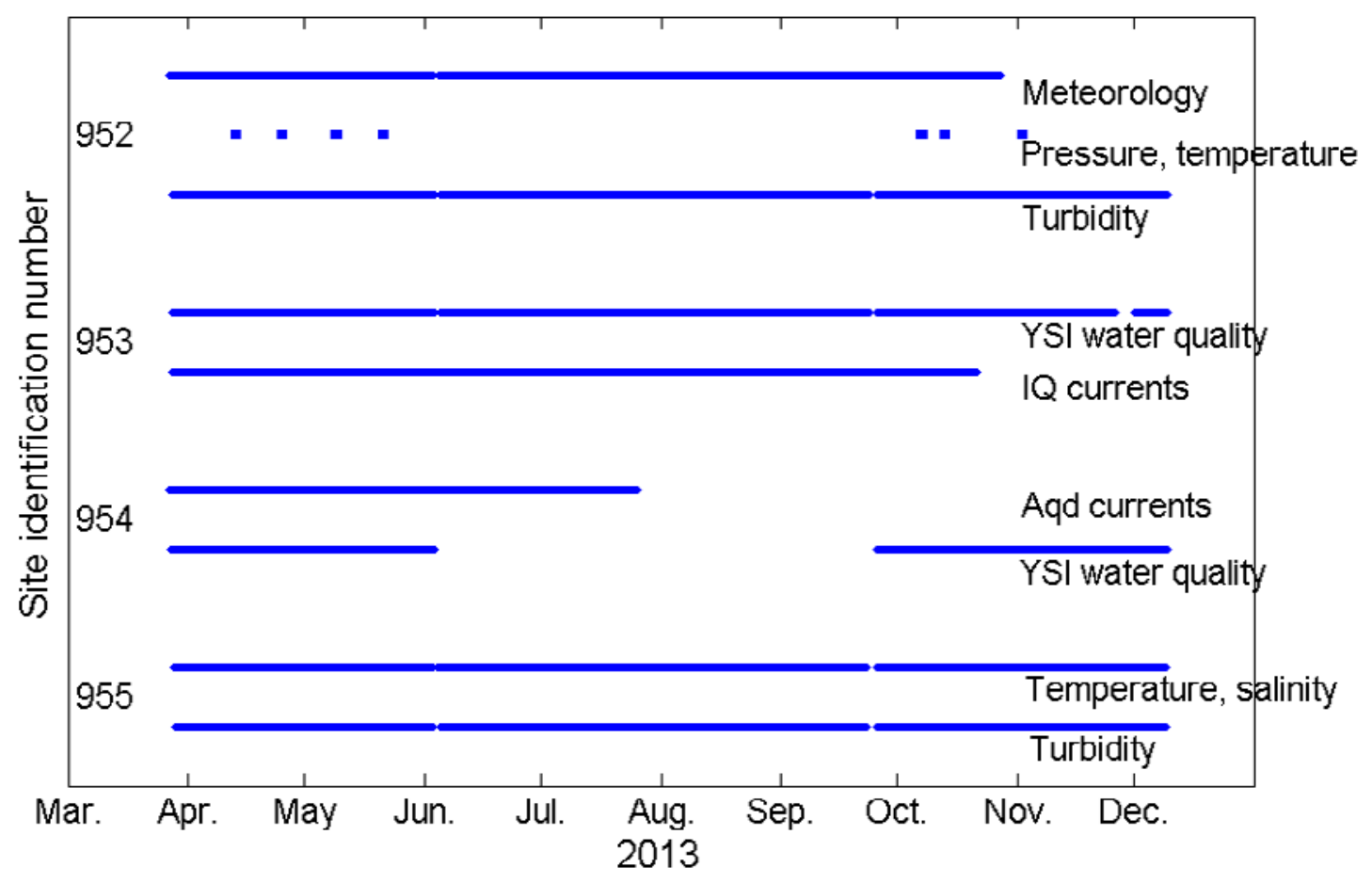

Figure 12. The data available for each sensor at each site between March 27 and December 9, 2013. The blue lines indicate when valid data exist, by sensor, at each site. YSI, SonTek/YSI 6-Series multiparameter sonde; IO, SonTek-IO flow monitor; Aqd, Nortek Aquadopp velocity profiler.

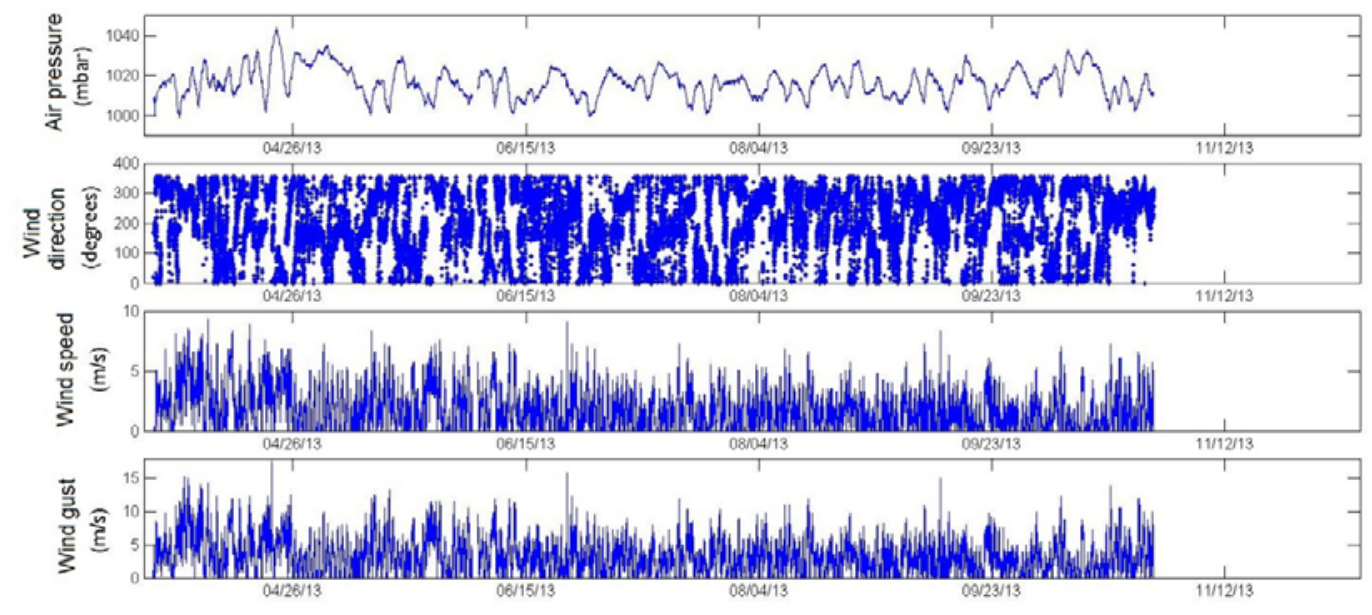

Figure 13. Barometric pressure and wind parameters from the meteorological station at site 952 between March 27 and December 9, 2013. The record ends early because of low battery in the Onset HOBO weather station. mbar, millibars; m/s, meters per second. 


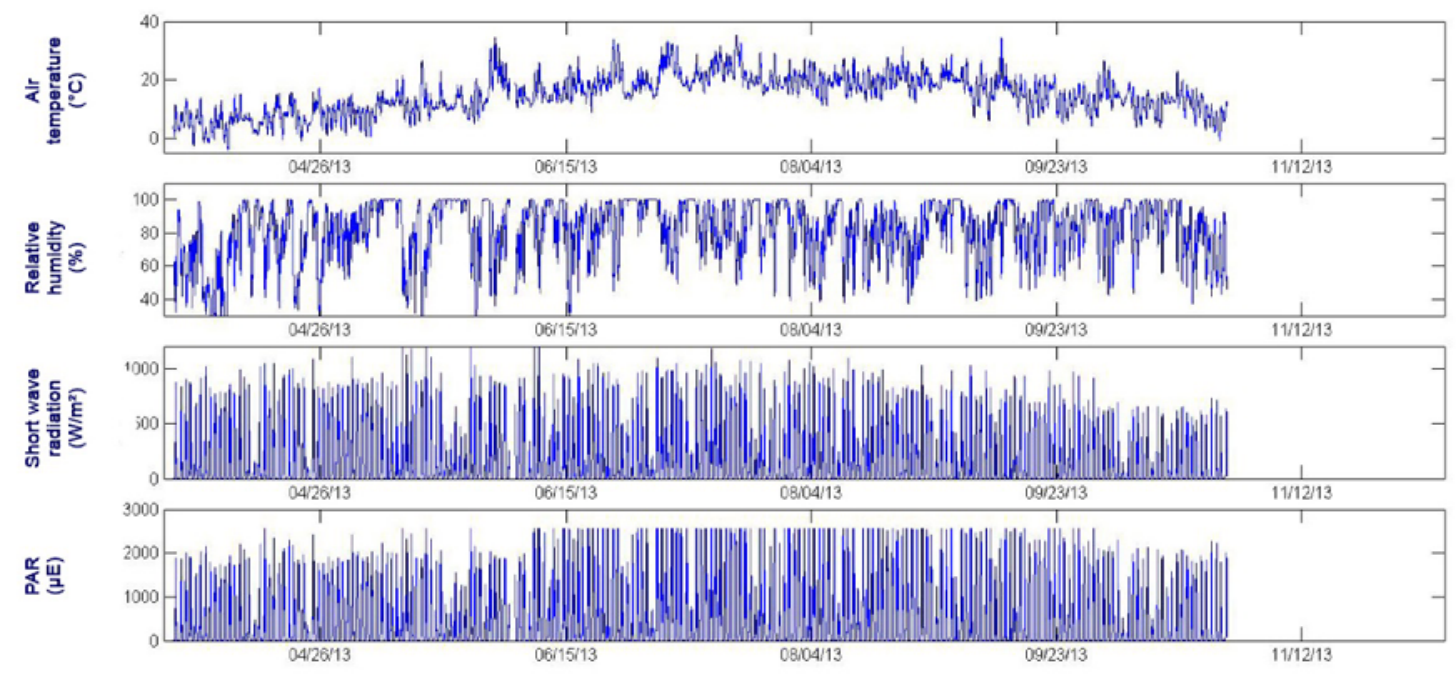

Figure 14. Air temperature, relative humidity, short wave radiation and photosynthetically active radiation (PAR) from the meteorological station at site 952 between March 27 and December 9, 2013. The record ends early because of low battery in the Onset $\mathrm{HOBO}$ weather station. ${ }^{\circ} \mathrm{C}$, degrees Celsius; \%, percent; $\mathrm{w} / \mathrm{m}^{2}$, watts per square meter; $\mu \mathrm{E}$, microeinsteins.

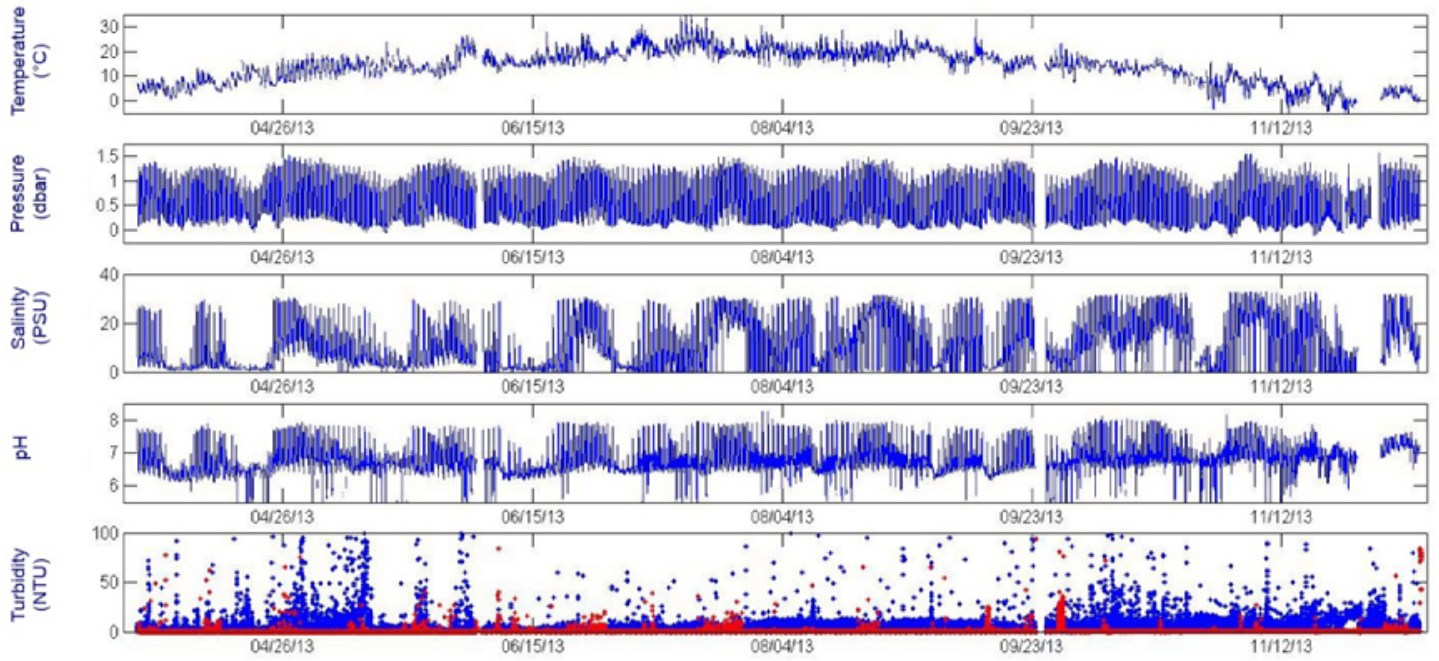

Figure 15. Water temperature, pressure, salinity, pH and turbidity at site 953, Furbish Road, between March 27 and December 9 , 2013. The turbidity from the marsh-top site (952) is overplotted in red. ${ }^{\circ} \mathrm{C}$, degrees Celsius; dbar, decibars; PSU, practical salinity units; NTU, nephelometric turbidity units. 


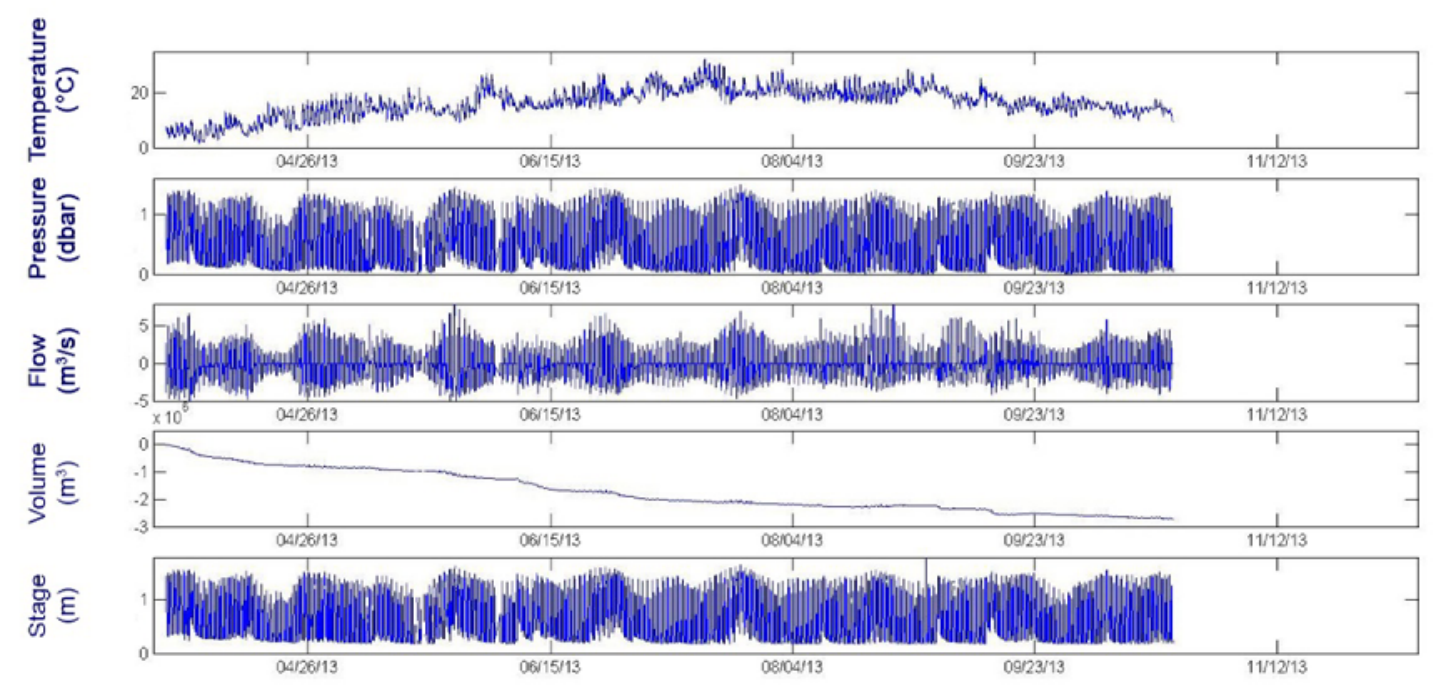

Figure 16. Water temperature, pressure, flow, volume, and stage from the SonTek-I0 flow monitor sensor at site 953, Furbish Road, between March 27 and December 9, 2013. The record ends early because of low battery in the SonTek-I0 flow monitor. ${ }^{\circ} \mathrm{C}$, degrees Celsius; dbar, decibars; $\mathrm{m}^{3} / \mathrm{s}$, cubic meters per second, $\mathrm{m}^{3}$, cubic meters; $\mathrm{m}$, meters.

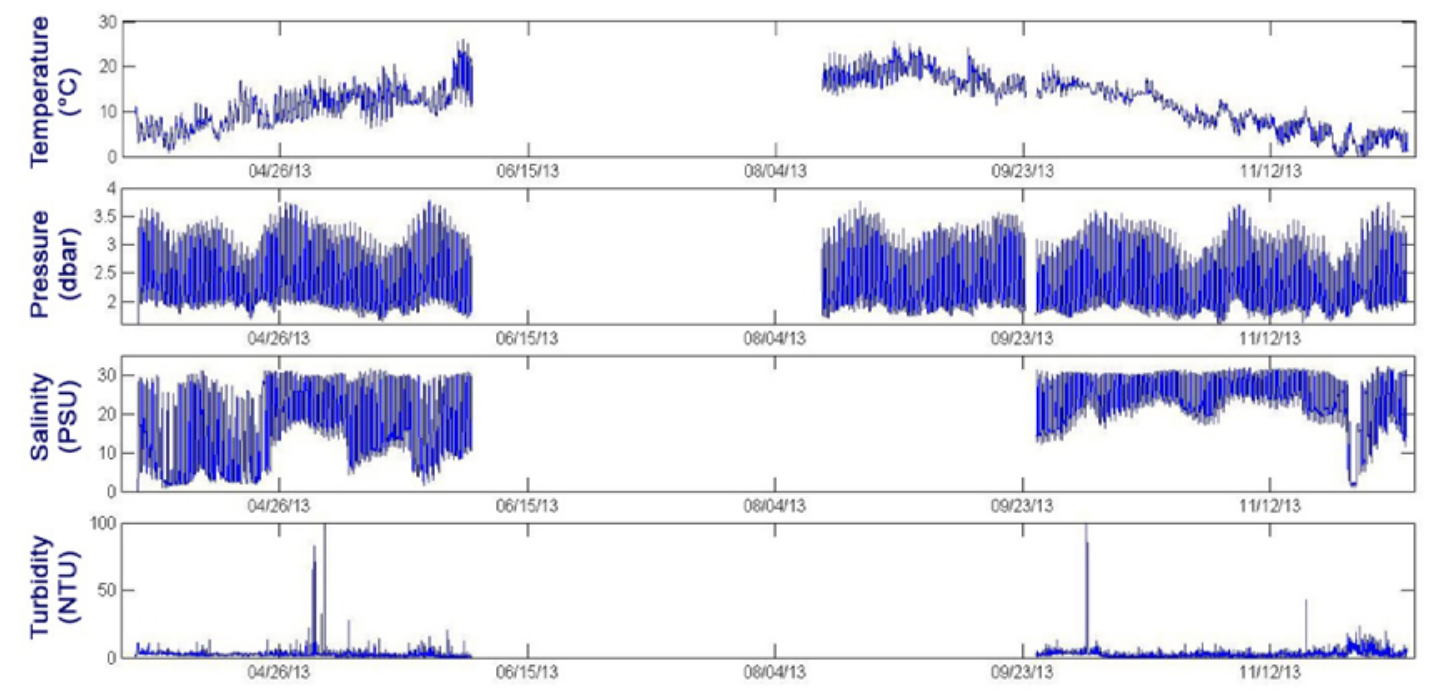

Figure 17. Water temperature, pressure, salinity and turbidity from the SonTek/YSI 6-Series sonde at site 954, Bourne Avenue, between March 27 and December 9, 2013. The gap in the middle is where instrument malfunction made the data unrecoverable. ${ }^{\circ} \mathrm{C}$, degrees Celsius; dbar, decibars; PSU, practical salinity units; NTU, nephelometric turbidity units. 

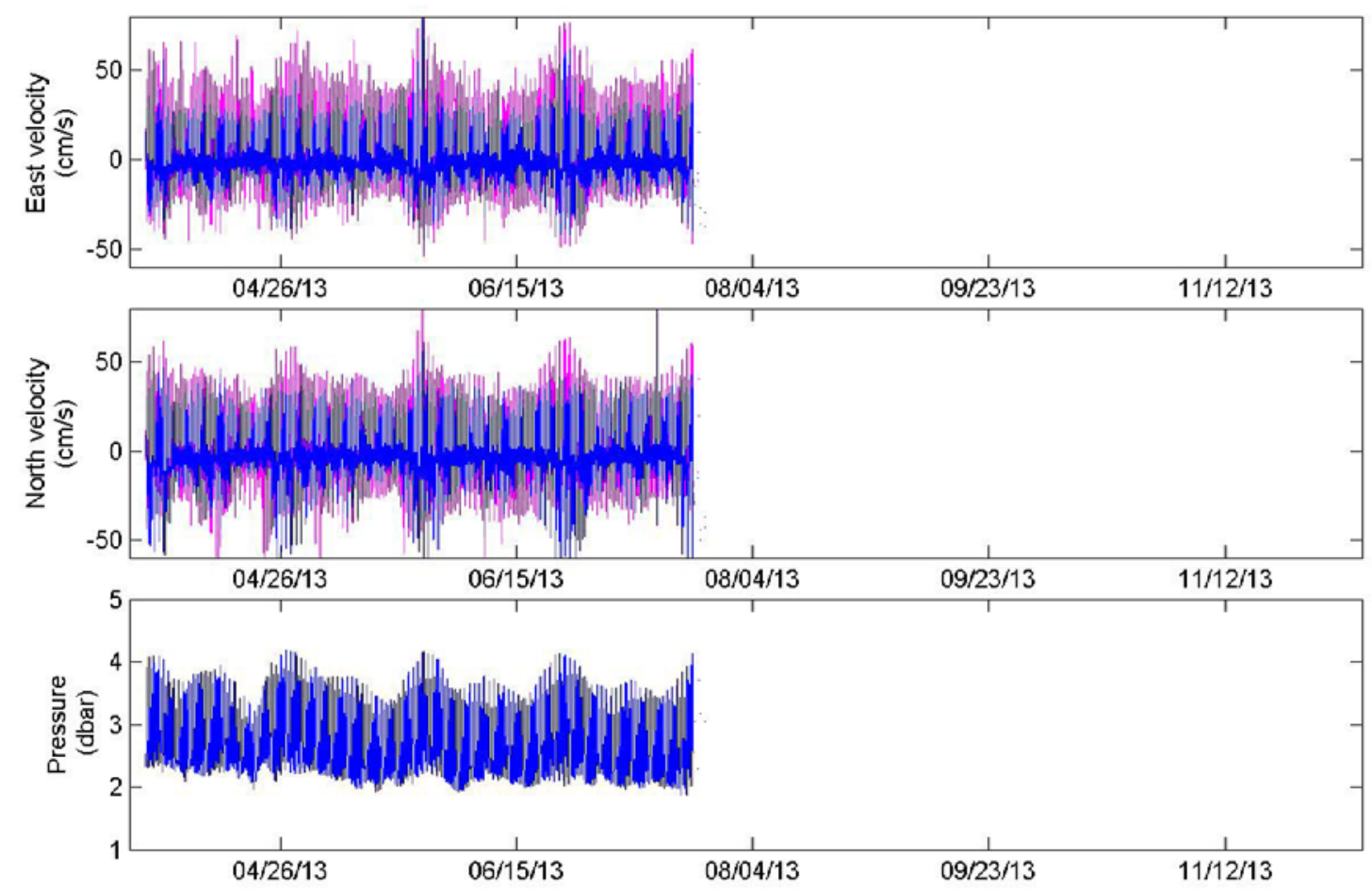

Figure 18. The east and north components of velocity and pressure from the Nortek Aquadopp velocity profiler at site 954, Bourne Avenue, between March 27 and December 9, 2013. In the top two frames, dark blue indicates the deepest bin, and pink indicates a near-surface bin. The record ends in mid-deployment because of sensor failure. dbar, decibars; $\mathrm{m} / \mathrm{s}$, meters per second. 


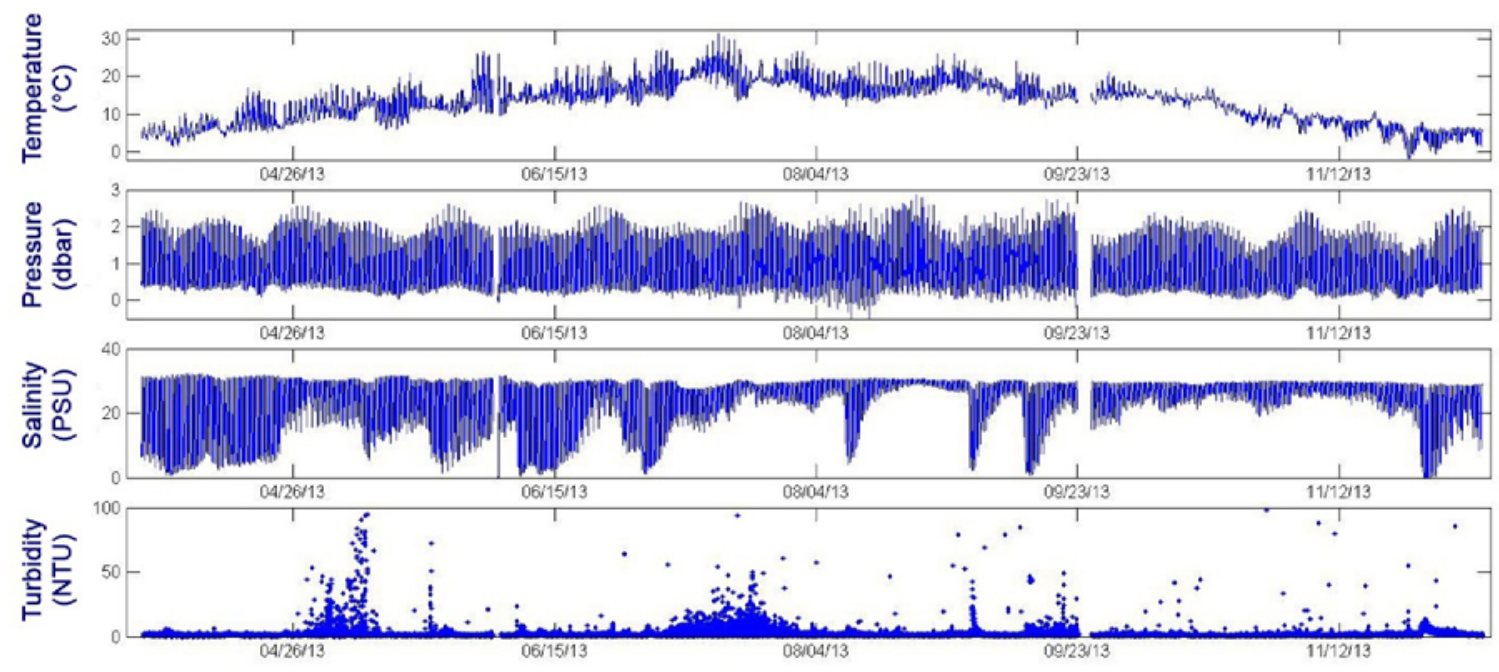

Figure 19. Water temperature, pressure, salinity, and turbidity from the Sea-Bird Electronics MicroCAT and Eco NTUSB sensors at site 955, the Ocean Avenue Footbridge, between March 27 and December 9, 2013. ${ }^{\circ} \mathrm{C}$, degrees Celsius; dbar, decibars; PSU, practical salinity units; NTU, nephelometric turbidity units. 


\section{Acknowledgments}

This study was run under the auspices of the U.S. Geological Survey (USGS) Coastal and Marine Geology Program and the Global Climate Change Program. Christine Sabens of the USGS provided logistical and field support for this program.

\section{References Cited}

Ganju, N.K., Dickhudt, P.J., Montgomery, E.T., Brennand, Patrick, Derby, R.K, Brooks, T.W., Guntenspergen, G.R., Martini, M.A., Borden, Jonathan, and Baldwin, S.M., 2012, Summary of oceanographic and water-quality measurements near the Blackwater National Wildlife Refuge, Maryland, 2011: U.S. Geological Survey Open-File Report 2012-1099, http://pubs.usgs.gov/of/2012/1099/.

Ganju, N.K., Dickhudt, P.J., Thomas, J.A., Borden, Jonathan, Sherwood, C.R., Montgomery, E.T., Twomey, E.R., and Martini, M.A., 2011, Summary of oceanographic and water-quality measurements in West Falmouth Harbor and Buzzards Bay, Massachusetts, 2009-2010: U.S. Geological Survey Open-File Report 2011-1113, http://pubs.usgs.gov/of/2011/1113/.

Ganju, N.K., Nidzieko, N.J., and Kirwan, M.L., 2013, Inferring tidal wetland stability from channel sediment fluxesObservations and a conceptual model: Journal of Geophysical Research—Earth Surface, v. 118, no. 4, p. 2045-2058, http://dx.doi.org/10.1002/jgrf.20143.

Montgomery, E.T., Ganju, N.K., Dickhudt, P.J., Borden, Jonathan, Martini, M.A., and Brosnahan, S.M., 2015, Oceanographic and water-quality measurements in Rachel Carson National Wildlife Refuge, Wells, Maine, 2013: U.S. Geological Survey data release, http://dx.doi.org/10.5066/F7ST7MWS.

Montgomery, E.T., Martini, M.A., Lightsom, F.L. and Butman, Bradford, 2008, Documentation of the U.S. Geological Survey oceanographic time series measurement database: U.S. Geological Survey Open-File Report 2007-1194, http://pubs.usgs.gov/of/2007/1194/. 


\section{Appendixes}

These appendixes provide access to non-Equatorial Pacific Information Collection (EPIC) convention-compliant supplementary data collected as part of the 2013 field campaign. These measurements include summaries of acoustic Doppler current profiler (ADCP) transects at Bourne Avenue and the channel dimensions at the Furbish Road site at the Rachel Carson National Wildlife Refuge, Maine. The raw ADCP data are available by request from the U.S. Geological Survey Woods Hole Coastal and Marine Geology Center, 384 Woods Hole Road, Quissett Campus, Woods Hole, MA 02543-1598 or by calling (508) 548-8700.

[Available separately at http://dx.doi.org/10.3133/ofr20151072.]

\section{Appendix 1. Acoustic Doppler Current Profiler Transects at the Bourne Avenue Site (Mooring 954) at the Rachel Carson National Wildlife Refuge, Maine, in April 2013}

[Table 1-1 contains total discharge with time-April 2013; table 1-2 contains detailed discharge measurements at Bourne Avenue-April 2013]

\section{Appendix 2. Acoustic Doppler Current Profiler Transects at the Bourne Avenue Site (Mooring 954) at the Rachel Carson National Wildlife Refuge, Maine, in May 2013}

[Table 2-1 contains total discharge with time-May 2013; table 2-2 contains detailed discharge measurements at Bourne Avenue-May 2013]

\section{Appendix 3. Channel Geometry at the Furbish Road Site (Mooring 953) at the Rachel Carson National Wildlife Refuge, Maine}

[Table 3-1 contains measurements of channel shape at Furbish Road site (mooring 953); figure 3-1 contains a diagram of channel shape from measurements in table $3-1]$ 

For more information concerning this report, contact: Director, Woods Hole Coastal and Marine Science Center

U.S. Geological Survey

384 Woods Hole Road

Quissett Campus

Woods Hole, MA 02543-1598

WHSC_science_director@usgs.gov

508-548-8700 or 508-457-2200

or visit our Web site at:

http://woodshole.er.usgs.gov/

Publishing support by:

The Pembroke Publishing Service Center. 


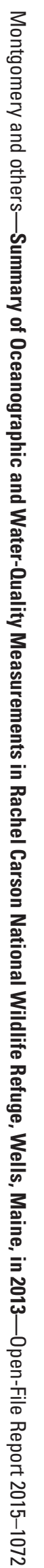

